\title{
Investigating The Effects of Activation Temperature on The Crystal Structure of Activated Charcoal From Palm Bunches (Arengga Pinnata Merr.)
}

\author{
Vivi Hastuti Rufa Mongkito ${ }^{1 *}$, Muhammad Anas², Wisda Puspita Bahar ${ }^{3}$ \\ ${ }^{123}$ Department of Physics Education, Universitas Halu Oleo \\ ${ }^{123}$ Jl. H.E.A Mokodompit Kendari Southeast Sulawesi 93231, Indonesia \\ Email: vivi.hastuti@uho.ac.id
}

\begin{abstract}
This research aims to determine the effect of activation temperature the crystal structure of activated charcoal. The material used activated charcoal bunches (Arengga Pinnate Merr). The process of making activated charcoal divided into two, namely the carbonization stage at a temperature of 250$400{ }^{\circ} \mathrm{C}$ and the activation stage at a temperature variation of $600-800^{\circ} \mathrm{C}$. To find the crystal structure, the sample characterized by X-Ray Diffraction. The results of analysis the dominant elements diamond before activation with a percentage of $90.2 \%$ and an orthorhombic crystalline structure, where the lattice parameter $\mathrm{a}=4.12700 \AA$; $\mathrm{b}=4.93700 \AA$; $\mathrm{c}=4.81900 \AA$. Peak Carbon has a hexagonal crystal structure in all temperature variations. Peak Graphite an orthorhombic crystal structure and at a temperature of $700{ }^{\circ} \mathrm{C}$ a hexagonal crystal structure formed. Therefore, giving temperature variations the activated charcoal of the bunches affects the structure of the formed Crystal. Wherein increasing the activation temperature, the crystal structure that forms look more amorphous marked by a widening diffraction peak intensity decreased crystals.
\end{abstract}

Keywords: Crystal structure, temperature activation, XRD, bunches of palm

\section{Introduction}

Bunches of the palm is a plant with many stems, which measure about two feet. All filled with fruit that is green when young and yellowish brown when ripe. Then, empty bunches where fruits used to process into food (Indonesia names kolang-Kaling) usually left dry or used as firewood. According to [1] his research component of chemical compounds included in waste palm bunches lignin is $27.74 \%$, $68.11 \%$ (hemicellulose), $33.79 \% \quad(\alpha$-cellulose), $11.10 \%$ water content extractive, so palm bunches are very high potential to be used as active charcoal.

Bunches of palm production function produces a variety of commodities that have high economic value and potentially serious export if cultivated, such as palm stems produce flour if palm sugar not intercepted and palm wood used as raw material for making furniture. All parts of the sugar plant have a production function and the function of conservation highly effective one to reduce Characterization directly into the ground to prevent erosion [2].

Some researchers have examined active charcoal made from palm bunches. Some of them [1] arguing that the activated charcoal of aren bunches consists of $\alpha$-cellulose isolation elements from palm bunches about 20-26\% and 16-21.33\% microcrystalline cellulose, with microcrystalline structures consisting of particles with a form irregular, odorless, white, tasteless, with $\mathrm{pH} 7.4$ and drying shrinkage 8.6\%. Microcrystalline cellulose powder of palm bunches has good flow properties, with a resting angle of 20.47 Ha, Hausner index of 1.19, and compressibility index of $18.6 \%$. Moreover, Hafiz et al., inform that microcrystalline cellulose pulp derived from oil palm empty fruit bunches filtered at room temperature and then dried in a vacuum oven at $105^{\circ} \mathrm{C}$ to constant weight reached. SIEMENS Difraktometer D5000 used to study the crystallinity of composite samples. XRD results explained that microcrystalline cellulose has its own or single cellulose structure with an $87 \%$ crystallinity index and a relatively high index of crystallinity with oil palm empty fruit pulp [3].

The yield of palm sugar leaves more bunches of sugar palm into the garbage. The trash from aren bunches is often considered useless and only becomes trash which turns out to have many 
benefits for the community because its utilization to date only limited to tapping flower bunches for processing palm sugar juice. One of the benefits of palm bunches rarely known the public it can use as activated charcoal or briquettes which can be used to absorb the waste solids dissolved in water, remove odors, absorption of dyes, purification agents [4].

Utilization of palm bunches intended in addition to tackling the buildup of waste and palm bunches expected to produce products that safe and environmentally friendly [5]. Research on activated charcoal from palm bunches is very rarely found in various literature because currently the most developed is research on active charcoal from oil palm bunches, although palm bunches made into charcoal as a raw material for making activated charcoal. However, the activation process technology to produce activated charcoal to the characteristics of the crystalline structure of the corresponding standards still faces many obstacles. By knowing the crystal structure of an element, it will get a little information about the origins of the elements, physical properties, and mechanical.

One of them is the method of X-ray diffraction (X-RD) where samples will be shot using $\mathrm{X}$-rays with wavelengths $A^{\cdot}$ scale corresponding to the lattice spacing of a material that is the measurement result is a diffractogram - considering the importance of knowing the information about the structure of the activated charcoal crystal. So that researcher interested in researching with the title "effect of activation temperature on the crystal structure of activated charcoal from palm bunches." This research aims to learn the effect of activation temperature on the crystalline structure of activated charcoal formed from palm bunches.

\section{Theory}

\section{The process of making activated charcoal}

Activated charcoal making process made employing carbonation pyrolysis method. Pyrolysis is a heating process in the absence of oxygen [6]. [7][8] stated that the pyrolysis is a process of incomplete combustion of a carbon-containing compound that not oxidized to $\mathrm{CO}_{2}$. Primary pyrolysis divided into a slow process at a temperature of $150{ }^{\circ} \mathrm{C}-300{ }^{\circ} \mathrm{C}$ which produces charcoal, $\mathrm{H}_{2} \mathrm{O}, \mathrm{CO}$ and $\mathrm{CO}_{2}$, and a fast process, transpires at temperatures of $300^{\circ} \mathrm{C}-400^{\circ} \mathrm{C}$, which produces charcoal, gas, and $\mathrm{H}_{2} \mathrm{O}$ [9]. After pyrolysis occurs at temperatures above $600^{\circ} \mathrm{C}$, which produce carbon monoxide, hydrogen gas, and hydrocarbon gases [10][11]. Next, [12] said states that when fast pyrolysis used (fast pyrolysis), heating for $0.1-0.5$ seconds at a temperature of $400^{\circ} \mathrm{C}-600^{\circ} \mathrm{C}$.

Authoring or carbonization process divided into four stages: (a) The evaporation stage of water, which occurs at temperatures of $100^{\circ} \mathrm{C}$ $150^{\circ} \mathrm{C}$; (b) Stage of decomposition of hemicellulose and cellulose at a temperature of $200^{\circ} \mathrm{C}-240^{\circ} \mathrm{C}$ into pyrogenic solution which a low boiling point organic acid such as acetic acid, formic acid, and methanol; (c) The stage of depolymerization and termination of $\mathrm{C}-\mathrm{O}$ and $\mathrm{C}$ $\mathrm{C}$ bonds, at a temperature of $240^{\circ} \mathrm{C}-400^{\circ} \mathrm{C}$. In addition, the lignin begins to decompose to produce tar, decreasing the pyroglinat and $\mathrm{CO}$ solution and increasing $\mathrm{CO}, \mathrm{CH} 4$, and hydrogen gas; (d) The stage of forming an aromatic layer, which occurs at temperatures more than $400^{\circ} \mathrm{C}$ and lignin, continues to decompose to a temperature of $500^{\circ} \mathrm{C}$, whereas at temperatures over $600^{\circ} \mathrm{C}$ there is a process of enlarging the surface area of charcoal. Furthermore, charcoal can be purified or turned into activated charcoal at a temperature of $500^{\circ} \mathrm{C}-1000^{\circ} \mathrm{C}$ [13][14][15].

\section{The crystal structure}

Crystalline structure is a condition or condition in which a typical arrangement of atoms in a crystal arranged specially and periodically repeats in three dimensions on a crystal lattice due the heating process resulting in more regular changes in the atomic structure [16]. The arrangement occurs because of geometric conditions that must meet the permanence of trending atomic bonds and tight arrangement. For knowing the crystal structure of an element, it will get a little information about the origins of the elements, physical properties, and mechanical.

Ideally, the most stable arrangement of polyhedra coordination is one that allows minimum energy per unit volume. This situation achieved if: a) electricity neutrality fulfilled; b) discrete and directed covalent bonds fulfilled; c) the repulsion force of ions becomes minimal; d) the arrangement of atoms as close as possible [17]. Lattice is an arrangement of points in three-dimensional space in which each point has a similar environment. The point with a similar environment named the lattice points. Knot lattice arranged only in 14 different configurations, named lattice Bravais. Based on the theory of the higher temperatures will increase the 
degree of crystallinity carbonized charcoal because of the high temperature capable of breaking the carbon chains that increasingly disordered arrangement of carbon atoms [18]. The degree of crystallization seen from the peaks of XRD which viewed from the value of the microcell origin/match three software

\section{Methodology}

This research conducted at the physics education laboratory Universitas Halu Oleo and XRD sample characterization at the energy laboratory of the Sepuluh Nopember Institute of Technology. The materials used are Arenga Pinnata Merr and using XRD (X-Ray Diffraction) characterization tools. The research stage divided into two stages, namely the carbonation stage at temperatures of $250-450^{\circ} \mathrm{C}$ and the activation phase of the sample starting from $600-800{ }^{\circ} \mathrm{C}$. The result of the analysis XRD in the form of an image of the activated crystalline charcoal structure of each bunch tested based on a comparison of temperature variations and a graph of the relationship of intensity and angle $2 \theta$ contained in each sample. The stages of the research described in Figure 1.

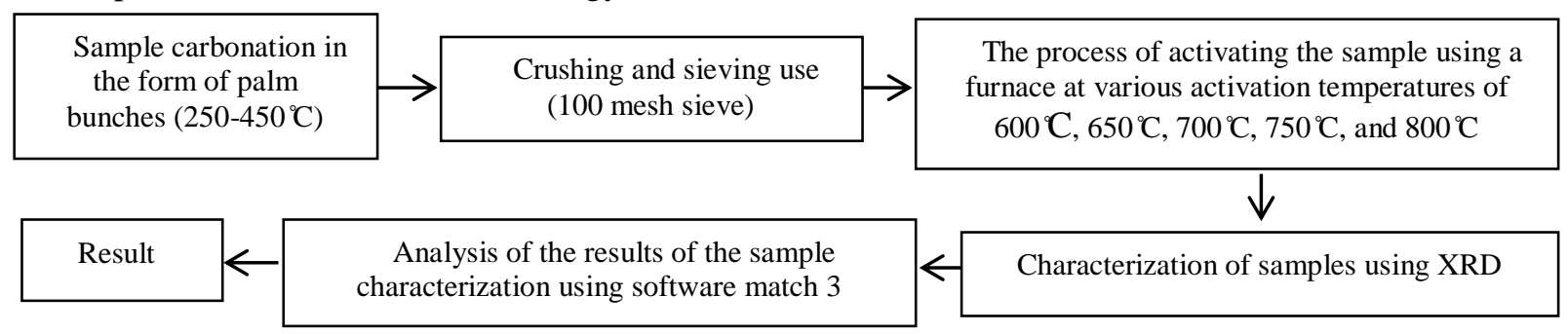

Figure 1. Research procedure

\section{Results and Discussion}

\section{Result}

In this study to determine the crystal structure of the activated charcoal from palm bunches before heated, $600{ }^{\circ} \mathrm{C}-800^{\circ} \mathrm{C}$ analyses by XRD, the source used $\mathrm{Cu}$ with a wavelength of $\lambda=1.54060$ $\AA$. The direct information obtained from the XRD test of palm bunches for various temperature variations the form of a spectrum or graph between scattering angles $(2 \theta)$ taken at a scattering angle of $5^{\circ}-60^{\circ}$. The diffractogram graph of the XRD results seen in Figure 2.

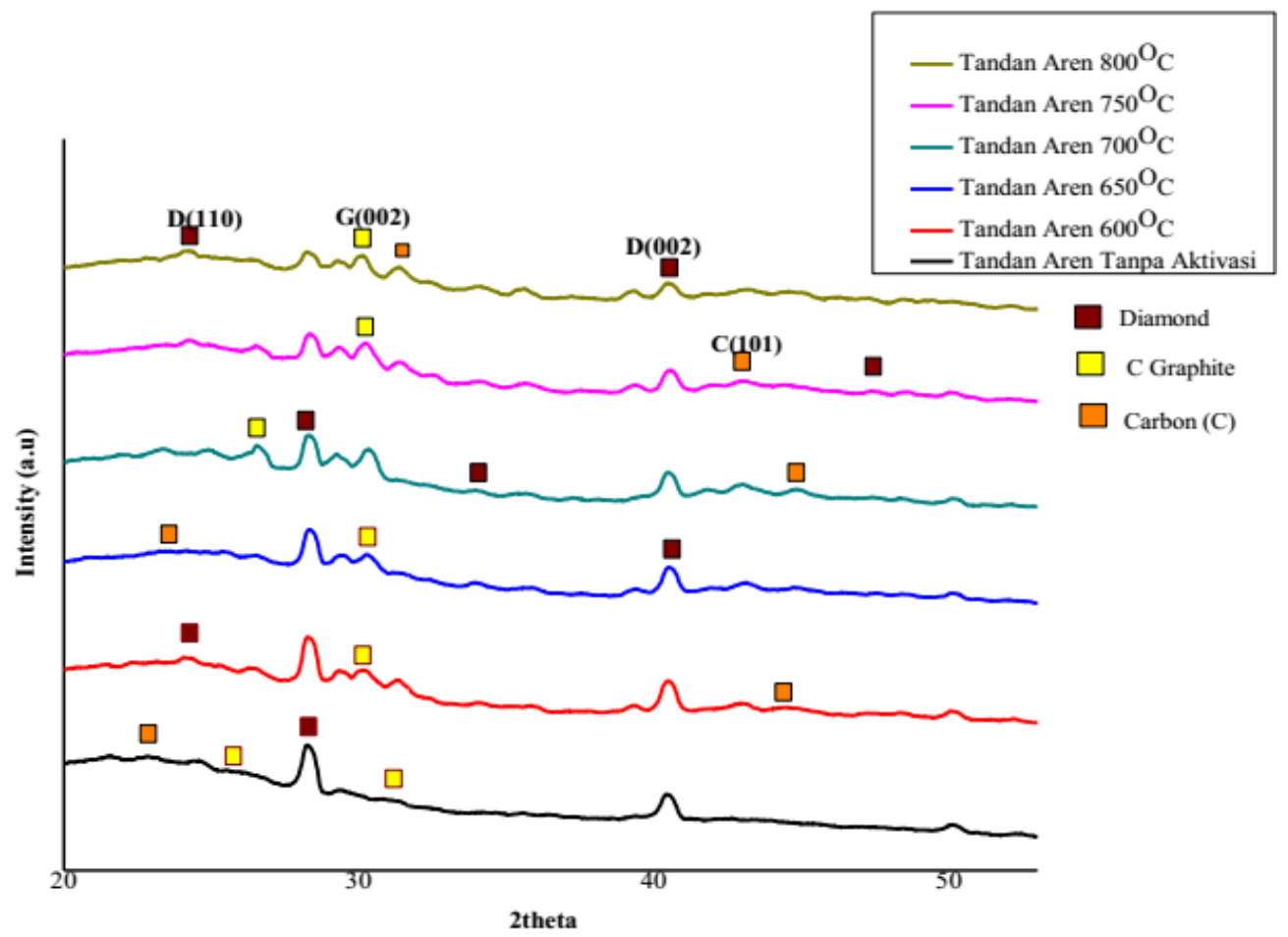

Figure 2. Graph of the Relationship of Intensity and $2 \theta$ in the Characteristics of Samples of Arsenic without Activation and Temperature of $600{ }^{\circ} \mathrm{C}$ to $800^{\circ} \mathrm{C}$ 
Figure 2 shows the change in diffraction peak as the activation temperature increases. A crystal structure assumed with a peak image where the position of the diffraction peak provides information about the lattice parameter, the shape of the crystal, while the relative intensity of the diffraction peak provides information about the position of the atom in a unit cell. To see the relationship between angles $2 \theta$ and counts, Match three software used, which then analyzed the peaks formed. From Match 3 software results obtained in the form of structure or shape of crystals, elements contained, percentage of content and lattice parameters $(\AA)$. The results of the analysis of match-three software seen in Table 1.

Table 1. Results of testing by the method of X-Ray Diffraction (XRD) analysis using software Match

\begin{tabular}{cllccc}
\hline $\begin{array}{c}\text { Temperature } \\
\left({ }^{\circ} \mathbf{C}\right)\end{array}$ & Crystal Structure & Component & Persentase & $\mathbf{2 \theta}$ & The lattice parameter $(\AA)$ \\
\hline \multirow{2}{*}{$\begin{array}{c}\text { Without } \\
\text { Activation }\end{array}$} & Orthorhombic & Diamond & $90,2 \%$ & $28,35^{\circ}$ & $\mathrm{a}=4.12700 \AA \mathrm{b}=4.93700 \AA \mathrm{c}=4.81900 \AA$ \\
& Orthorhombic & Graphite & $5,7 \%$ & $25,70^{\circ}$ & $\mathrm{a}=4.52500 \AA \mathrm{b}=5.33400 \AA \mathrm{c}=5.92500 \AA$ \\
& Hexagonal & Carbon & $4,1 \%$ & $23,12^{\circ}$ & $\mathrm{a}=4.89000 \AA \mathrm{c}=3.88000 \AA$ \\
\hline \multirow{2}{*}{600} & Orthorhombic & Diamond & $38,1 \%$ & $24,23^{\circ}$ & $\mathrm{a}=4.87000 \AA \mathrm{b}=5.56500 \AA \mathrm{c}=4.40600 \AA$ \\
& Orthorhombic & Graphite & $15,8 \%$ & $30,07^{\circ}$ & $\mathrm{a}=4.57500 \AA \mathrm{b}=5.30400 \AA \mathrm{c}=5.63500 \AA$ \\
& Hexagonal & Carbon & $46,1 \%$ & $43,67^{\circ}$ & $\mathrm{a}=2.52210 \AA \mathrm{c}=12.35570 \AA$ \\
\hline \multirow{2}{*}{650} & Orthorhombic & Diamond & $57,4 \%$ & $40,54^{\circ}$ & $\mathrm{a}=4.96400 \AA \mathrm{b}=5.16300 \AA \mathrm{c}=4.38700 \AA$ \\
& Orthorhombic & Graphite & $21,4 \%$ & $30,02^{\circ}$ & $\mathrm{a}=4.52500 \AA \mathrm{b}=5.33400 \AA \mathrm{c}=5.92500 \AA$ \\
& Hexagonal & Carbon & $21,1 \%$ & $22,66^{\circ}$ & $\mathrm{a}=4.89000 \AA \mathrm{c}=3.88000 \AA$ \\
\hline \multirow{2}{*}{700} & Orthorhombic & Diamond & $49,3 \%$ & $28,34^{\circ}$ & $\mathrm{a}=4.12700 \AA \mathrm{b}=4.93700 \AA \mathrm{c}=4.81900 \AA$ \\
& Hexagonal & Graphite & $8,7 \%$ & $26,69^{\circ}$ & $\mathrm{a}=2.45600 \AA \mathrm{c}=6.69600 \AA$ \\
& Trigonal & Carbon & $42,0 \%$ & $44,58^{\circ}$ & $\mathrm{a}=2.52210 \AA \mathrm{c}=43.24500 \AA$ \\
\hline \multirow{2}{*}{750} & Orthorhombic & Diamond & $66,3 \%$ & $47,31^{\circ}$ & $\mathrm{a}=4.12700 \AA \mathrm{b}=4.93700 \AA \mathrm{c}=4.81900 \AA$ \\
& Orthorhombic & Graphite & $7,0 \%$ & $30,22^{\circ}$ & $\mathrm{a}=4.57500 \AA \mathrm{b}=5.30400 \AA \mathrm{c}=5.63500 \AA$ \\
& Hexagonal & Carbon & $26,7 \%$ & $42,86^{\circ}$ & $\mathrm{a}=2.52210 \AA \mathrm{c}=8.23710 \AA$ \\
\hline \multirow{2}{*}{800} & Orthorhombic & Diamond & $84,6 \%$ & $24,23^{\circ}$ & $\mathrm{a}=4.87000 \AA \mathrm{b}=5.56500 \AA \mathrm{c}=4.40600 \AA$ \\
& Orthorhombic & Graphite & $12,5 \%$ & $30,09^{\circ}$ & $\mathrm{a}=4.52500 \AA \mathrm{b}=5.33400 \AA \mathrm{c}=5.92500 \AA$ \\
& Hexagonal & Carbon & $2,9 \%$ & $31,20^{\circ}$ & $\mathrm{a}=4.89000 \AA \mathrm{c}=3.88000 \AA$ \\
\hline
\end{tabular}

Furthermore, the characteristics of the crystalline material determined by atomic bonds in the crystal, the orientation of the crystal plane. The distance between the crystal plane and the crystal system. The typical arrangement of atoms in crystals called a crystal system or crystal structure. Diffraction is the process of X-ray scattering by crystal material. The XRD method uses an X-ray which diffracted as a ray reflected from each plane, formed with crystal atoms from the material each sample with different temperature variations, it will produce a different diffraction pattern from the samples.

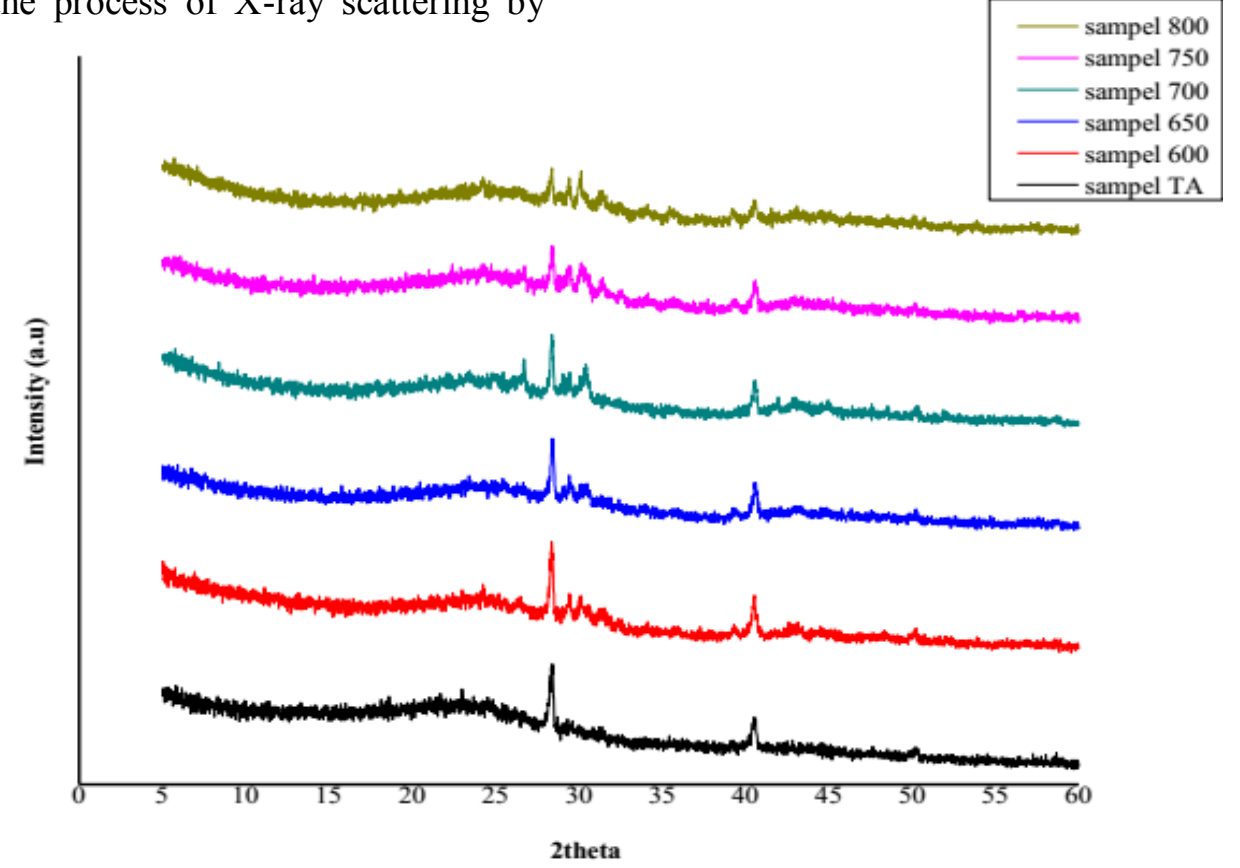

Figure 3. Diffractogram samples palm bunches on pre-heating and temperature of $600{ }^{\circ} \mathrm{C}-800{ }^{\circ} \mathrm{C}$ 
Based on the graph (Figure 3) of measurement results with the XRD with the assisted of software match 3 before heated, $600{ }^{\circ} \mathrm{C}, 650{ }^{\circ} \mathrm{C}, 700^{\circ} \mathrm{C}$, $750{ }^{\circ} \mathrm{C}, 800^{\circ} \mathrm{C}$ shows that the resulting diffraction peak contains diamond elements, graphite, and carbon which not periodic and the actual diffraction peaks formed leads to crystalline graphite. Although the higher the activation temperature diffraction peaks, more dominant amorphous form characterized by irregular peaks generated. Crystal diffraction peaks formed at each temperature change the intensity of the diffraction peak, either increasing or decreasing.

\section{Discussion}

This study aims to determine the description of the crystalline structure formed in activated charcoal bunches using XRD (X-Ray Diffraction). The results of the analysis explain that there is a shift in the diffraction peaks towards the angle $2 \theta$ higher near the peak of graphite $\left(26^{\circ}\right)$ and new peaks appear around the $30^{\circ}$ and $40^{\circ}$ angles (Figure 3). Peak $26^{\circ}$ and $40^{\circ}$ characterize graphite in a flat plane (Planar L), whereas at angle $27^{\circ}-28^{\circ}$ is a graphite crystal structure in the vertical plane. At different temperatures, the diffraction peak of the crystal formed at an angle of $28^{\circ}$ still appears, what changes is the intensity of the peak diffraction. Manocha argues that the arrangement of activated carbon particles is allotropic, which can change from one crystal cell unit structure to another at a specific temperature [19].

The statement confirmed from the analysis of the samples sixth graph, the crystal structure changes, and the angular position of each element, obtained as a result of the given temperature. After the search Software match 3, on active charcoal samples, bunches of palm-based diffractogram (Figure 2) with different temperature variations arise diffraction peaks typically. The highest diffraction peak around the corner $2 \theta: 28.39^{\circ}$ from the peak formed seen that in some of the top structure already shows the crystal structure although not periodic. The second known that the crystal structure has energy peaks sharp and narrow and at some of the top chart above shows the characteristics mentioned crystal structure located around the corner $28,35^{\circ}, 30^{\circ}, 40,54^{\circ}$. Although a relatively small diffraction intensity showed, an amorphous structure is more dominant than the crystal structure.

The crystal structure formed at a temperature of $700{ }^{\circ} \mathrm{C}$ more transforms the diffraction peak shifts due to the vibration of atoms where the graphite element forms a hexagonal crystal structure which initially at a temperature of $650{ }^{\circ} \mathrm{C}$ with an orthorhombic structure. It evidenced by the percentage of graphite content from the sample before heated, which is $5.7 \%$ to $15.8 \%$ at a temperature of $600^{\circ} \mathrm{C}$ and increases to $21.4 \%$ at a temperature of $650^{\circ} \mathrm{C}$, but the decline in temperatures $700^{\circ} \mathrm{C}$ is $8.7 \%$. This data reinforced from the study of [20-21] that on X-ray investigation showing that microscopic crystalline activated charcoal is similar to graphite structure, where graphite consists of some plates arranged in parallel, and each plate has a hexagonal system with six carbon atom. With increasing temperatures given, the type of the element at some angle $2 \theta$ obtained will vary from one temperature to another temperature. Other materials also have a hexagonal crystal structure is $\mathrm{CdSe}$ or compounds of cadmium and selenium that widely used in solar cell technology. In the study [22-23] the thin layer of $\mathrm{CdSe}$ formed a polycrystalline crystal with a hexagonal crystal system. Changes in crystal structure with different materials have also studied [24] stated that the transformation of pyrolusite minerals with a tetragonal structure a cubic bixbyite structure than to tetragonal hausmannite occurred due to increased sintering temperature causing structural changes in manganese seeds.

Based on XRD analysis (Figure 2) when this diamond element fitting process found at the angles of $2 \theta\left(28^{\circ}\right.$ and $\left.40^{\circ}\right)$, but further research is needed to see if in certain circumstances diamonds can be amorphous or vice versa and still need to be verified by the existence of diamonds with other characterizations such as Raman Spectroscopy. The principle of Raman Spectroscopy is the interaction between light and the sun that uses a beam of monochromatic light such as a laser. Scattering through the sample cause the frequency shift and yielding information on vibration, rotation, or other low-frequency transition in the molecule and capable of providing a fingerprint where the molecules identified. Because generally the making of diamond elements not easy, so other proofs needed with different characterizations. Based on research conducted by [25] regarding the Raman Spectroscopy study of diamond and graphite in ureilite and the origin of diamonds explain that Raman Spectroscopy is a useful and non-destructive tool for checking the properties of carbon materials. Raman Spectroscopy studies to obtain information about diamond and graphite properties in ureilite. Graphite quickly produced with diamonds when the proportions of $\mathrm{H}_{2}$ and 
$\mathrm{CH}_{4}$ change slightly. Notably, high $\mathrm{CH}_{4}$ content seems to support the growth of graphite. Graphite in ureilite is well arranged compared to carbon material in chondroitin carbon. Domain dimensional graphite is estimated at 45-110 A: Shifting the position the diamond peak to higher wave numbers seem to support the chemical vapor deposition of diamond origin ureilite containing carbon matrix. Its silicon coarse-grained (millimeter) and regarded as the accumulation of magma ultrasonic or partial melting residues.

However, impressive results appear where at a temperature of $700^{\circ} \mathrm{C}$ at an angle of $30.38^{\circ}$, the diffraction peak does not experience a decrease in intensity after the diffraction peak temperature of $650^{\circ} \mathrm{C}$ widens. The decline in the intensity of the diffraction peaks are clues to start the formation of aromatic compounds [26]. The compound is a constituent of hexagonal crystalline charcoal and activated charcoal structures. In Smallman's and [27-28] explained the effect of heating on the structure of minerals that formed is that the properties of the material will change if given treatment such as heating on the resources of manganese seeds. These events can be explained by physics when seed manganese samples heated at a precise temperature, the mineral structure changes in manganese ore samples into a new mineral which is also beneficial for the industry. Changes in the structure of manganese ore minerals can occur due to temperature sintering.

The changing structure of the material due to the temperature also caused when a material is heated; there will be an increase in energy, which allows the atoms vibrate at interatomic distances higher [29]. The higher the energy applied, the distance between atoms would be getting away. For a certain level of energy (temperature), atoms can get away from each other more quickly and are more difficult to suppress. The influence of energy on the distance between atoms, namely the more significant the energy yielded, the distance between atoms will be further away. Changing the spacing between atoms will affect the structure of the material.

\section{Conclusion}

From the results of the analysis of sugar palm bunches samples with six types of temperature treatment obtained by the dominating element is diamond found in the sample without activation with a percentage of $90.2 \%$ with an orthorhombic crystal structure. Giving the heating temperature variation or activated charcoal palm bunches affect the structure of the crystals formed. Where the temperature of activation increases, the structure of the formed Crystal is more amorphous, which is characterized by the irregularity of the resulting peak.

\section{Acknowledgment}

Our thanks to Physics Education Laboratory Universitas Halu Oleo and Energy Laboratory Sepuluh Nopember Institute of Technology for all assistance and facilities provided to the author so that this research completed

\section{References}

[1] Sumaiyah, B. Wirjosentono, and Karsono, "Utilization of Microcrystalline Cellulose of Sugar Palm Bunches (Arengapinnata (Wurmb) Merr.) as excipients Tablet Direct Compression," International Journal of PharmTech Research, vol. 9, no. 7, pp. 130-139, 2016.

[2] Heyne. K, Tumbuhan Berguna Indonesia, Edisi II. Jakarta: Yayasan Sarana Wana Jaya, 1987.

[3] M. K. M. Haafiz et al., "Microcrystalline Cellulose from Oil Palm Empty Fruit Bunches as Filler in Polylactic Acid," Polymers \& Polymer Composites, vol. 24, no. 9, pp. 675-680, 2016.

[4] F. Schuchardt, D. Darnoko, and P. Guritno, "Composting of Empty Oil Palm Fruit Bunch (EFB) With Simultaneous Evaporation Of Oil Mill Waste Water (POME)," International Oil Palm Conference, 2002, pp. 1-9.

[5] I. Udoetok, "Characterization of ash made from oil palm empty fruit bunches," International Journal of Environmental Sciences, vol. 3, no. 1, pp. 1-8, 2012.

[6] Haygreen and G. John, Hutan dan Kehutan. Yogyakarta: UGM Press, 1986.

[7] K. Kinoshita, "Electrochemical Uses of Carbon," Electrochemistry Encyclopedia. The electrochemical society is advancing solid-state and electrochemical science and technology, pp. 1-5, 2019.

[8] L. Kavan, "Electrochemical Carbon," Chemical Review, vol. 97, no. 9, pp. 3061-3082, 1997.

[9] M. Lempang and Hermin Tikupadang, "Application of Candlenut Shell Activated Charcoal as a component in Seedling Culture Medium of Gmelina arborea Roxb.," Jurnal Penelitian Kehutanan Wallacea, vol. 2, no. 2, pp. 121-137, 2013.

[10] O. Paris, C. Zollfrank, and G. A. Zickler, "Decomposition and Carbonisation of Wood Biopolymers - a Microstructural Study of Softwood Pyrolysis," Journal of Carbon, vol. 43, no. 8, pp. 53-66, 2005.

[11] A. G. Haji, Z. Alim, B. W. Lay, S. H. Sutjahjo, and G. Pari, "Characterization of Liquid Smoke Pyrolyzed," Journal Teknik Industri pertanian, vol. 16, no. 3, pp. 111-118, 2007.

[12] T. A. Fahmy, "Biomass pyrolysis: past, present, and future," Environment, Development and Sustainability, vol. 18, no. 6, pp. 1-16, 2018.

[13] D. B, S. Ketaren, and S. Setyahartini, Pengolahan Arang dan Kegunaanya. Bogor: IPB Press, 1985. 
Mongkito et al.

[14] Masthura and Zulkarnain, "Karakterisasi Mikrostruktur Karbon Aktif Tempurung Kelapa dan Kayu Bakau," JElkawnie: journal of Islamic Science and Technology, vol. 4, no. 1, pp. 45-54, 2018.

[15] A. Budianto, E. Kusdarini, S. S. W. Effendi, and M. Aziz, "The Production of Activated Carbon from Indonesian Mangrove Charcoal," IOP Conf. Series: Materials Science and Engineering, vol. 012006, no. 462, pp. 1-8, 2019.

[16] S. V Kailas, "Material Science," Indian Institute of Science, 2012

[17] M. Kurniati, D. Nurhayati, and A Maddu, "Study of Structural and Electrical Conductivity of Sugarcane Bagasse-Carbon with Hydrothermal Carbonization," IOP Conf. Series: Earth and Environmental Science, vol. 012049, no. 58, pp. 1-7, 2017.

[18] Z. Z. Chowdhury et al., "Effect of Temperature on the Physical, Electro-Chemical and Adsorption Properties of Carbon Micro-Spheres Using Hydrothermal Carbonization Process," Nanomaterial, vol. 8, no. 8, pp. 1-19, 2018.

[19] S. M. Manocha, "Porous carbons," SADHANA, vol. 28, no. $1-2$, pp. 335-348, 2003.

[20] A. Kienle and M. S. Patterson, "Determination of the optical properties of turbid media from a single Monte Carlo simulation," Physics Medicine Biology, vol. 2221, no. 41, pp. 1-8, 1996.

[21] A. P. Sandi and Astuti, "Pengaruh Waktu Aktivasi Menggunakan $\mathrm{H}_{3} \mathrm{PO}_{4}$ Terhadap Struktur Dan Ukuran Pori Karbon Berbasis Arang Tempurung Kemiri (Aleurites moluccana)," Jurnal Fisika Unand, vol. 3, no. 2, pp. 115-120, 2014.

[22] Arisman, "Hasil Preparasi dengan Teknik Close Spaced Vapor Transport (CSVT)," Prosiding Pertemuan Ilmiah XXVII HFI Jateng \& DIY, 2013, pp. 97-102.

[23] V. Starikov, M. Ivashchenko, and A. S. Opanasyuk, "Surface morphology and optical properties of cdse films obtained by the close-spaced vacuum sublimation technique," Journal Nano-Electron Physics, vol. 3, no. 2, pp. 45-54, 2009.

[24] P. J. Putri, Ratnawulan, and Gusnedi, "Analisis Struktur Bijih Mangan Hasil Proses Sinter yang Terdapat Di Nagari Kiawai Kecamatan Gunung Tuleh Kabupaten Pasaman Barat," Pillar of Physics, vol. 5, no. 4, pp. 105-112, 2015.

[25] K. Nagashima, M. Nara, and J. Matsuda, "Raman spectroscopic study of diamond and graphite in ureilites and the origin of diamonds," Meteoritics \& Planetary Science, vol. 1737, no. 11, pp. 1728-1737, 2012.

[26] Y. Kimura, T. Sato, and C. Kaito, "Production and structural characterization of carbon soot with narrow UV absorption feature," Journal of Carbon, vol. 42, pp. 33-38, 2004.

[27] R. E. Smallman, Metalurgi Fisik Moderen, Edisi enam. Jakarta: Erlangga, 2003.

[28] H. Syukriani, A. Budiman, and D. Puryanti, "dan Struktur Stronsium Ferit $\left(\mathrm{SrFe}_{12} \mathrm{O}_{19}\right)$ Pasir Besi Batang Sukam Kabupaten Sijunjung Sumatera Barat," Jurnal Fisika Unand, vol. 6, no. 3, pp. 225-231, 2017.

[29] V. Vlack and L. H, Ilmu dan Teknologi Bahan. Jakarta: Erlangga, 1995.
Investigating the effects of activation temperature on the crystal structure... 